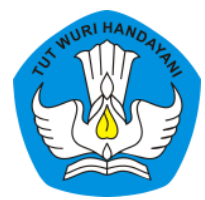

Page: $399-420$

\title{
MODEL PEMBELAJARAN ROLEX BERBANTUAN MEDIA BONETER MENINGKATKAN KEAKTIFAN DAN KETERAMPILAN BERBICARA TEKS DESCRIPTIVE
}

\author{
Yuli Arisandi \\ Sekolah Menengah Negeri Pertama 2 Wanadadi, Jawa Tengah, Indonesia \\ Contributor Email: yuliarisandi77@gmail.com
}

Received: Feb 07, 2021

Accepted: Jun 30, 2021

Published: Mar 30, 2021

Article Url: https:/ /ojsdikdas.kemdikbud.go.id/index.php/didaktika/article/view/247

\begin{abstract}
The research was aimed at improving the student's activeness and speaking skill by using role exchange model and character doll media. The research consisted two cycles. The procedures were: planning, implementation, observation and reflection. The study used two data. The qualitative data through observation the student's activeness in learning process. The quantitative data were obtained by speaking test performance. The students' activeness with high score in preliminary observation reached 5 students $(17,86 \%)$ improved 23 students $(82,14 \%)$ in Cycle II. It can be seen that all students paid attention their teacher, engaged in problem solving and applied they learned. Most of them also had ideas and gave the questions. The data of the speaking skill assessment in preliminary observation showed that 42,85\% (12 students) got the same score or above KKM with the average 61,77 increased $89.29 \%$ (23 students) with the average score was 77.3 in second cycle. Improvement was significant especially in student's vocabulary mastery, comprehension and fluency. While, grammar and pronunciation improved although was not significant. The conclusion of this research is that: (1) the student's speaking skill improves from the previous condition, first cycle and then second cycle; 2) the students' activeness in English teaching learning also improves.
\end{abstract}

Keywords: Activeness; Speaking Skill; Role Exchange; Character's Doll 


\begin{abstract}
Abstrak
Penelitian ini bertujuan meningkatkan keaktifan dan keterampilan berbicara bahasa Inggris siswa melalui model pembelajaran role exchange berbantuan media boneka karakter. Penelitian ini terdiri dari dua siklus. Tahapan penelitian ini meliputi empat tahapan yaitu merencanakan, menerapkan tindakan, pengamatan, dan refleksi. Penelitian menggunakan dua data. Data kualitatif diperoleh melalui keaktifan siswa dalam pembelajaran. Data kuantitatif diperoleh dengan memberi test kemampuan berbicara. Siswa yang keeaktifannya tinggi pada kondisi awal hanya 5 siswa atau 17,86\% meningkat manjadi 23 siswa atau 82,14\% pada siklus II. Hal ini terlihat semua siswa memperhatikan guru, terlibat dalam pemecahan masalah, mengaplikasikan materi pelajaran yang diperolehnya, sebagian sudah berani mengeluarkan ide dan bertanya. Data keterampilan berbicara pada kondisi awal menunjukkan 42,85\% mendapat nilai yang sama atau diatas KKM dengan rata-rata $61,77 \%$ meningkat menjadi 89,29\% dengan nilai rata-rata 77,3 pada siklus kedua. Peningkatan secara signifikan pada aspek penguasaan kosa kata, pemahaman dan kelancaran. Sementara tata bahasa dan pengucapan meningkat meskipun tidak tajam. Kesimpulan penelitian ini adalah (1) keterampilan berbicara siswa terus meningkat dari kondisi awal, siklus pertama kemudian siklus kedua dan (2) keaktifan siswa dalam kegiatan belajar mengajar bahasa Inggris meningkat.
\end{abstract}

Kata Kunci: Keaktifan, Keterampilan Berbicara; Bertukar Peran; Boneka Karakter

\title{
A. Pendahuluan
}

Menteri Pendidikan dan Kebudayaan (2016) tentang Peraturan Menteri Pendidikan Nasional No. 22 Tahun 2016 mengenai Standar Proses Pembelajaran pada Satuan Pendidikan Dasar dan Menengah menyatakan bahwa proses pembelajaran pada satuan pendidikan dasar dan menengah diselenggarakan secara interaktif, inspiratif, menyenangkan, menantang, memotivasi siswa untuk berpartisipasi aktif, serta memberikan ruang yang cukup bagi prakarsa, kreativitas, dan kemandirian sesuai dengan bakat, minat, dan perkembangan fisik serta psikologis siswa. Dengan kata lain pembelajaran selain menekankan pada hasil juga harus memperhatikan proses yang tepat untuk mencapai tujuan pembelajaran. Bahasa adalah merupakan sarana untuk berkomunikasi, oleh karena itu penulis mengangkat keterampilan berbicara pada penelitian ini dengan keaktifan siswa sebagai proses untuk mencapai tujuan pembelajaran. 
Menurut Sudjana (2001) keaktifan siswa dalam mengikuti proses belajar mengajar dapat dilihat dalam: partisipasi siswa dalam melaksanakan tugas belajarnya, keterlibatan dalam pemecahan masalah, bertanya pada guru maupun siswa lain apabila tidak memahami persoalan yang dihadapinya, berusaha mencari informasi yang dibutuhkan untuk memecahkan masalah, melaksanakan diskusi kelompok berdasarkan petunjuk guru, mampu menilai kemampuan diri dan hasil yang diperolehnya, berlatih memecahkan soal atau masalah sejenis dan mampu menggunakanataumenerapkan apa yang telah diperolehnya.

Pengamatan pada kondisi awal menunjukkan bahwa dari sejumlah 28 siswa, hanya 5 siswa atau sebesar 17,86\% yang terlihat mempunyai keaktifan yang tinggi. Lainnya, sebanyak 12 siswa atau sebesar 42,86\% kategori keaktifan sedang, dan selebihnya 11 siswa atau sebesar 39,29\% kategori keaktifan rendah. Harmer (2001) yang menyatakan bahwa syarat seseorang mempunyai keterampilan berbicara secara lancar adalah punya pengetahuan tentang ciri-ciri bahasa dan mampu memproses informasi bahasa tersebut. Rendahnya keterampilan berbicara bahasa Inggris ditunjukkan pada saat pembelajaran bahasa Inggris yang dilaksanakan di SMP Negeri 2 Wanadadi Banjarnegara di kelas VIIA yang berjumlah 28 siswa menunjukkan hanya 12 siswa $(42,86 \%)$ mempunyai nilai yang sama atau melewati KKM bahasa Inggris di sekolah ini yaitu 65 dengan nilai rata-rata 61,77 .

Secara garis besar yang membuat keaktifan dan keterampilan berbicara rendah dikarenakan hal-hal berikut. Guru jarang berkomunikasi dalam bahasa Inggris. Guru lebih mendominasi dalam proses pembelajaran siswa lebih banyak mendengar tapi kurang melakukan praktik berbicara bahasa Inggris. Mereka kurang aktif karena tidak menguasai keterampilan berbicara dan takut salah dan ditertawakan teman-temannya. Kenyataan yang terjadi dalam pembelajaran bahasa Inggris juga karena penggunaan media yang kurang tepat, sehingga pembelajaran kurang menarik dan 
menjadikan kurang konkret dan efisien dalam menjelaskan sesuatu. Pada akhirnya, keterampilan berbicara dan keaktifan siswa menjadi rendah yang dibuktikan dengan hasil penilaian pada kompetensi berbicara dan observasi dengan siswa.

Macam-macam metode dan model pembelajaran antara lain meliputi model pembelajaran project based learning diskusi, penugasan, discovery, inquiry dan lain-lain begitupun media yang digunakan audio, visual, media yang dibuat sendiri atau yang memanfaatkan lingkungan sekitar.Solusi untuk menyelesaikan rendahnya keaktifan siswa dan keterampilan berbicara bahasa Inggris yang digunakan dalam penelitian ini adalah model pembelajaran rolex dengan media boneter. Pengertian rolex (role exchange) dalam penelitian ini adalah kreasi atau inovasi serangkaian proses kegiatan berganti peran yang memacu siswa untuk dapat berbicara dan menghasilkan suatu produk teks bahasa Inggris.

Media "boneter" juga akronim dari kata boneka karakter. Boneter adalah boneka tangan yangterbuat dari kain perca yang dibuat sendiri oleh siswa. Boneter diwujudkan dalam tokoh dan karakter tertentu yang akan menjadi pembelajaran bagi siswa. Dari tokoh Boneter akan dimunculkan dan ditanamkan karakter yang baik. Siswanti, dkk (2013) menyebutkan boneka tangan adalah tiruan dalam bentuk manusia, hewan maupun bentuk lainnya yang ukurannya disesuaikan dengan ukuran tangan dengan berbagai corak dan motif.

Penerapan inovasi pembelajaran menggunakan model pembelajaran rolex dengan media boneter ini diharapkan menjadi pilihan dalam pembelajaran bahasa Inggris untuk meningkatkan keaktifan dan keterampilan berbicara bahasa Inggris pada siswa kelas VIIA sehingga siswa mempunyai nilai keterampilan berbicara rata- rata sama atau diatas 65 dengan ketuntasan belajar sama atau melebihi $75 \%$ di kelas ini.

Penelitian ini merujuk pada penelitian yang dilakukan oleh Budi Pratiwi (2013) dengan judul penelitian Meningkatkan Keterampilan Berbicara Bahasa Inggris dengan Menggunakan Media Video di SMA Berbudi Yogyakarta. 
Kesimpulan penelitiannya adalah media video dapat membantu meningkatkan keterampilan berbicara bahasa Inggris siswa dengan ketuntasan belajar 75,10\%. Selanjutnya adalah penelitian yang dilakukan oleh Mutia Rahmah (2019) dengan judul Penggunaan Flavid pada Procedure Text untuk Meningkatkan Kemampuan Berbicara Bahasa Inggris. Berdasarkan hasil penelitianpenelitian tersebut, penulis menyimpulkan bahwa media pembelajaran tersebut mampu meningkatkan keterampilan berbicara bahasa Inggris dengan rata-rata nilai $7,41 \%$ siswa yang tuntas belajar di siklus pertama kemudian meningkat menjadi 74, 07\%.

Secara umum penelitian ini bertujuan untuk meningkatkan keaktifan siswa dan keterampilan berbicara teks descriptive. Secara khusus penelitian ini bertujuan untuk (1) Mendeskripsikan peningkatan keaktifan siswa melalui model pembelajaran rolex berbantuan media boneter (2) Mendeskripsikan peningkatan keterampilan berbicara teks descriptive melalui model pembelajaran rolex berbantuan media boneter.

\section{B. Metode}

Subyek penelitian ini adalah keaktifan dan keterampilan berbicara pada siswa kelas VIIA SMP Negeri 2 Wanadadi berjumlah 28 siswa. Siswa terdiri dari 15 siswa perempuan dan 13 siswa laki-laki dengan karakteristik siswa memiliki potensi dan kompetensi yang heterogen. SMP Negeri 2 Wanadadi tersebut tempat peneliti melaksanakan tugas mengajar sehingga tidak mengganggu kegiatan belajar mengajar.

Penelitian ini dilakukan dengan menggunakan metode penelitian tindakan kelas terdiri dari 2 siklus. Prosedur umum penelitian ini melalui tahapan perencanaan (planning), pelaksanaan tindakan (acting/implementing), pengamatan (observing) dan refleksi (reflecting)

\section{Rencana Tindakan}

Pada bagian ini, peneliti melakukan perencanaan tindakan untuk meningkatkan keaktifan dan keterampilan berbicara siswa melalui penerapan model pembelajaran rolex berbantuan media boneter, dengan langkah-langkah sebagai berikut: 
1) Menetapkan setting dan waktu pelaksanaan penelitian dengan 2 siklus dan tiap siklus 3 pertemuan;

2) Menetapkan materi pembelajaran, yaitu kompetensi dasar pengetahuan: 3.7 membandingkan fungsisosial, struktur teks, dan unsur kebahasaan beberapa teks deskriptif lisan dan tulis dengan memberi dan meminta informasi terkait dengan deskripsi orang, binatang, dan benda sangat pendek dan sederhana, sesuai dengan konteks penggunaannya. Kompetensi dasar keterampilan: 4.7.1 menangkap makna secara kontekstual terkait fungsisosial, struktur teks, dan unsur kebahasaan teks deskriptif lisan dan tulis, sangat pendek dan sederhana, terkait orang, binatang, dan benda;

3) Membuat ijin, rekomendasi penelitian dari kepala sekolah dan pernyataan kesediaan sebagai kolaborator;

4) Menyusun rancangan penelitian tindakan kelas dan jurnal kegiatan penelitian;

5) Menyusun rencana pelaksanaan pembelajaran dengan lembar kerja siswa, media dan instrumen keterampilan berbicara bahasa Inggris;

6) Menyusun lembar observasi yang terdiri (a) lembar penilaian menyusun rencana perbaikan pembelajaran, (b) lembar observasi keaktifan siswa, (c) lembar observasi pelaksanaan pembelajaran;

7) Menyusun instrumen proses belajar;

8) Menyusun daftar hadir siswa;

9) Menyusun daftar hadir guru dan kolaborator;

10) Menyusun deskripsi pelaksanaan;

11) Menentukan jadwal pelaksanaan refleksi.

\section{Pelaksanaan Tindakan dan Pengamatan}

Peningkatan keaktifan dan keterampilan berbicara Teks descriptive dalam penelitian ini dilakukan melalui skenario pembelajaran penggunaan model pembelajaran rolex berbantuan media boneter. Menurut Trianto (2014) pendekatan yang luas dan menyeluruh serta 
dapat mengklasifikasikan berdasarkan tujuan pembelajarannya, sintaks (pola urutannya) dan sifat lingkungan belajaranya disebut sebagai model pembelajaran. Salah satu model pembelajaran untuk memacu siswa berbicara bahasa Inggris adalah dengan menerapkan sebuah model pembelajaran rolex (role exchange) atau dalam bahasa Indonesia mempunyai arti bertukar peran. Model ini adalah kreasi dari penulis berdasarkan permasalahan yang dihadapi siswanya dalam melaksanakan pembelajaran berbicara bahasa Inggris.

Model pembelajaran ini bertujuan membuat siswa lebih memahami dan mendalami suatu dialog atau percakapan dengan tidak hanya mengalami dan mempraktikkan satu sisi sebagai peran orang pertama tapi juga bergantian dengan mengalami dan mempraktikkan sisi sebagai orang kedua dan seterusnya. Dengan demikian seorang siswa akan memahami keseluruhan percakapan dan diharapkan juga terampil mempraktikan sebuah percakapan dengan peran orang pertama atau orang kedua dan seterusnya.

Syntax role exchange ada 6 tahap yaitu: Tahap I: Siswa diberi contoh sebuah teks percakapan terkait materi pelajarannya itu teks descriptive tentang manusia (friends, sisters, brothers, teachers, etc) dan hewan (tiger, rabbit, lion, panda, etc). Guru membacakan, siswa menirukan. Dalam tahapan ini juga diperkenalkan beberapa kata sukar untuk dibahas. Tahap II: Siswa memahami ungkapan yang dipakai (What is your sister like? She is... What does she look like? She has.... What does she usually do? She usully..., she likes....

Tahap III: Siswa berlatih menggunakan dialog/percakapan yang disediakan guru secara berpasangan, kemudian berganti peran (orang pertama kemudian bergantian menjadi orang kedua). Misal orang pertama bertanya orang kedua menjawab dan kemudian bergantian. Tahap IV: Siswa dikelompokkan yang terdiri dari 2 atau 4 orang setiap kelompoknya. Merancang sebuah dialog dengan menggunakan boneka tangan masing-masing dengan karakter masing-masing. Misalkan, Momo (boneter): ciri-ciri fisik (physical apperances): handsome, tall, has curly hair, .... 
Sifat (character): Kind herated, patient, diligent..., kebiasaan (habit): He likes help people, he never angry, He studies everyday.... Dari 4 siswa diusahakan tidak punya ciri-ciri fisik, karakter dan kebiasaan yang sama supaya kosakatanya berkembang.

Tahap V: Siswa praktik berbicara dengan sebuah teks yang sejenis di kelompok masing-masing. TahapVI: Siswa mempraktikkan sebuah percakapan secara berkelompok. Tahap VII: Siswa mendiskusikan percakapan yang telah dipraktikkan dan mendapat masukan dan penilaian I dari guru. Tahap VIII: Siswa bertukar peran dan berlatih mempraktikkan percakapan sesuai permintaan penilai. Tahap IX: Siswa praktik percakapan di depan kelas. Tahap X: Siswa mendapatkan koreksi, evaluasi, masukan, dan penilaian dari penilai II.

Instrumen untuk mengukur keberhasilan tindakan diambil dari dua sisi yaitu proses dan hal yang diamati. Dari sisi bagan alirnya, instrumen dalam PTK menjangkau pembahasan yang berkaitan dengan input (kondisi awal), proses (saat pelaksanaan), dan output (hasil). Instrumen dikelompokkan menjadi 3 (tiga), yaitu: instrumen untuk mengamati kelas (observing classroom), instrumen untuk mengamati guru (observing teachers) dan instrumen untuk mengamati siswa (observing students).

Instrumen yang digunakan untuk pengamatan tentang penerapan model pembelajaran rolex berbantuan media boneter dilakukan saat proses pembelajaran yaitu alat penilaian kemampuan guru mengajar (APKG) terdiri dari 20 aspek, yaitu (1) mengerjakan tugas rutin kelas; (2) mengajukan pertanyaan menantang terkait apersepsi dan keaktifan siswa; (3) mengaitkan materi sebelumnya berdasarkan pengalaman siswa; (4) menyampaikan kompetensi yang akan dicapai dalam kegiatan pembelajaran; (5) menyampaikan skenario dan rencana kegiatan yang dilakukan siswa; (6) menggunakan model pembelajaran rolex berbantuan media boneter; (7) menggunakan berbagai sumber belajar kemampuan siswa; (8) menguasai materi pembelajaran sesuai KD; (9) memfasilitasi kegiatan siswa melakukan 
eksplorasi, elaborasi, konfirmasi; (10) menerapkan urutan pembelajaran yang logis dan sistematis; (11) melakukan pembelajaran yang dapat menumbuhkan sikap spiritual dan sosial; (12) melibatkan siswa untuk terlibat aktif dalam proses pembelajaran; (13) menggunakan waktu pembelajaran secara efektif dan efisien; (14) menunjukkan sikap terbuka, suasana kondusif dan keceriaan; (15) menggunakan bahasa Indonesia yang baik dan benar; (16) memberi kesempatan siswa melakukan keterampilan dan mengomunikasikan; (17) melaksanakan penilaian selama proses pembelajaran berlangsung; (18) menyimpulkan hasil pembelajaran dan refleksi; (19) melakukan tes lisan, tertulis dan mengumpulkan karya siswa untuk portofolio, dan (20) memberikan rencana tindak lanjut.

Pada penelitian ini teknik dan alat pengumpulan data menggunakan tes, pengamatan dan dokumentasi; Tes yang digunakan adalah tes keterampilan berbicara bahasa Inggris. Tes keterampilan berbicara adalah tes yang dilaksanakan oleh siswa untuk mengetahui penguasaan pengetahuan atau keterampilan berbicara sebagai hasil prestasi belajar yang ditunjukkan dengan nilai atau angka yang diberikan oleh guru.

Langkah yang dilakukan dalam menyusun tes keterampilan berbicara bahasa Inggris meliputi: menyusun kisi-kisi, membuat butir soal/tugas, dan membuat rubrik, norma dan tabel penilaian. Instrumen yang digunakan untuk mengetahui keterampilan berbicara bahasa Inggris adalah tes praktik.

Penilaian keterampilan berbicara siswa menurut Brown, (2004) mengukur keterampilan berbicara menjadi enam kategori, yaitu dari segi tata bahasa, kosakata, pemahaman, kefasihan, pengucapan dan tugas.

Penilaian keterampilan berbicara pada penelitian ini ada 5 kategori yaitu: kosa kata (vocabulary), kelancaran (fluency), pengucapan (pronunciation), tata bahasa (grammar), dan pemahaman (comprehension). Kategori ini sesuai dengan yang dikatakan oleh Harmer (2001) yang menyatakan bahwa syarat seseorang mempunyai keterampilan berbicara secara lancar tidak 
hanya dari pengetahuan tentang ciri-ciri bahasa, tetapi juga dari kemampuan memproses informasi bahasa tersebut.

Pengamatan yang digunakan dalam penelitian ini meliputi pengamatan tentang keaktifan siswa, penerapan model pembelajaran rolex berbantuan media boneter dalam proses pembelajaran dan pengamatan perilaku siswa. Menurut Sudjana (2001) kriteria keaktifan siswa dalam mengikuti proses belajar mengajar adalah: adanya partisipasi terhadap tugas belajar yang diberikan, ikut serta dalam pemecahan masalah, apabila tidak memahami persoalan bertanya kepada siswa lain atau guru, ada usaha untuk mendapatkan informasi untuk memecahkan masalah, diskusi kelompok dilaksanakan sesuai petunjuk guru, mampu menilai kemampuan diri dan hasil yang diperolehnya dengan baik, berlatih memecahkan masalah soal dan sejenisnya dan apa yang diperolehnya digunakan atau diterapkan.

Langkah yang dilakukan dalam menyusun instrumen keaktifan siswa meliputi: menyusun kisi-kisi, menyusun butir pernyataan, menentukan teknik dan jenis pengukuran, dan menyusun lembar pengamatan. Instrumen yang digunakan untuk mengamati variabel keaktifan siswa menggunakan lembar pengamatan keaktifan siswa terdiri dari 4 aspek, yaitu: memperhatikan guru, mengeluarkan ide dan bertanya, berlatih memecahkan masalah, dan kemampuan mengaplikasikan apa yang diperolehnya.

Instrumen yang digunakan untuk pengamatan perilaku siswa berupa anekdotal deskripsi pembelajaran penerapan model pembelajaran rolex berbantuan media boneter terdiri dari perilaku pada proses pendahuluan, proses kegiatan inti dan proses penutup.

Dokumentasi yang digunakan dalam penelitian ini adalah dokumen pra siklus tentang keaktifan siswa, keterampilan berbicara serta dokumen perangkat pembelajaran. Peneliti juga menggunakan dokumentasi foto kegiatan pembelajaran. Dokumentasi foto dilakukan pengambilannya pada saat pembelajaran berlangsung sebagai bukti fisik 
kegiatan pembelajaran. Pengambilan foto kegiatan di kelas dibantu seorang teman dengan kondisi peneliti dan siswa dalam keadaan yang sewajarnya, apa adanya atau tidak dibuat-buat.

Validasi data menggunakan data tes, data pengamatan, dan data dokumentasi. Data tes keterampilan berbicara bahasa Inggris. Data keterampilan berbicara yang divalidasi adalah instrumen tes maka validasinya menggunakan menggunakan validasi empirik dan validasi teoritik yaitu analisis kualitatif dan kuantitatif. Data Pengamatan; Validasi data dilakukan dengan menggunakan triangulasi sumber, triangulasi metode, dan triangulasi peneliti. Pada penelitian ini triangulasi sumber menggunakan sumber data yang berbeda-beda yaitu data tentang proses pembelajaran melalui siswa dan guru kolaborator. Keaktifan siswa dilakukan triangulasi yaitu dengan pengamatan siswa, wawancara yang mendalam dan observasi guru kolaborator. Selain triangulasi di atas penelitian ini menggunakan triangulasi peneliti yaitu hasil penelitian diuji validasinya dari peneliti terdahulu. Data Dokumentasi; Data awal keterampilan berbicara siswa menggunakan data praktik berbicara bahasa Inggris.

Pada penelitian ini analisis data yang pertama adalah analisis data tes keterampilan berbicara. Guna mencapai tujuan yang telah dirumuskan dalam penelitian ini, penulis menggunakan teknik analisis data kuatitatif. Data ini dalam PTK umumnya berupa angka-angka sederhana, seperti nilai tes hasil belajar, distribusi frekuensi, prosentase, skor dan lain-lain. Data kuantitatif dapat dianalisis secara deskriptif antara lain dengan cara menghitung jumlah, rata-rata (rerata), nilai prosentase, membuat grafik dan sebagainya.

Analisis tersebut dilakukan dengan langkah-langkah sebagai berikut. (1) Menghitung skor yang diperoleh siswa dengan rubrik dan tabel penilaian; (2) Menghitung skor tertinggi, terendah dan median; (3) Menghitung ketuntasan belajar siswa; (4) Menghitung nilai rata-rata Hasil tes keterampilan berbicara dengan analisis statistik deskriptif untuk membandingkan rata-rata hasil tes 
dengan indikator kinerja, menggunakan teknik analisis kecenderungan nilai tengah (central tendensy) yaitu mencari nilai rata-rata (mean).

Analisis data kedua adalah data keaktifan siswa dalam pembelajaran. Analisis dilakukan setiap satu paket perbaikan selesai dilaksanakan secara keseluruhan. Penelitian ini satu siklus perbaikan dilaksanakan tiga kali pertemuan pembelajaran, maka analisis data pengamatan yang dilakukan setelah ketiga pertemuan selesai dilaksanakan. Analisis dilakukan dengan langkah-langkah (1) menghitung skor yang diperoleh siswa dengan lembar pengamatan, (2) menghitung skor keaktifan siswa tinggi, sedang dan rendah, (3) menghitung skor keaktifan siswa belajar, dan (4) menghitung keaktifan siswa.

Lembar pengamatan keaktifan siswa terdiri dari 4 Aspek, yaitu (1) memperhatikan guru, (2) mengeluarkan ide dan bertanya, (3) berlatih memecahkan masalah, dan (4) mengaplikasikan apa yang diperolehnya. Jumlah aspek pengamatan 4 butir pernyataan, jika hasil pengamatan 1 aspek maka keaktifan siswa rendah, 2-3 aspek yang tercukupi maka keaktifan siswa sedang dan 4 aspek dicapai semua berarti keaktifan siswa tinggi.

Dokumentasi untuk kemampuan awal menggunakan data nilai keterampilan berbicara bahasa Inggris sebelumya dengan langkahlangkah analisis meliputi (1) menghitung skor yang diperoleh siswa dengan norma dan tabel penilaian, (2) menghitung skor tertinggi, terendah dan median, (3) menghitung ketuntasan belajar siswa, dan (4) menghitung nilai rata-rata.

Hasil tes keterampilan berbicara dengan analisis deskriptif untuk membandingkan rata-rata hasil tes dengan indikator kinerja, maka digunakan teknik analisis kecenderungan nilai tengah (Centraltendensy) yaitu mencari nilai rata-rata (mean). Ketuntasan belajar menggunakan kriteria ketuntasan belajar 65, untuk menghitung ketuntasan klasikal dengan membandingkan jumlah siswa yang tuntas dengan jumlah siswa di kelas.

Model pembelajaran rolex berbantuan media boneter meningkatkan keaktifan siswa. Hal ini terlihat semua siswa memperhatikan guru, 
terlibat dalam pemecahan masalah dan mengaplikasikan materi pelajaran yang diperolehnya dan sebagian sudah berani mengeluarkan ide dan bertanya. Keterampilan berbicara siswa dalam praktik saat proses pembelajaran mengalami peningkatan pesat pada aspek kosa kata, pemahaman, dan kelancaran, dari segi tata bahasa dan pengucapan juga meningkat walaupun tidak sebesar tiga aspek yang telah disebutkan.

Data hasil pengamatan di atas selanjutnya dianalisis sebagai bahan melakukan refleksi. Kegiatan refleksi dilakukan setelah selesai proses tindakan pada pertemuan III. Hal-hal yang dilakukan pada saat refleksi adalah (1) Melakukan analisis keaktifan siswa; (2) Melakukan analisis keterampilan berbicara bahasa Inggris; (3) Melakukan analisis kemampuan guru dalam menyusun rencana pembelajaran dengan alat penilaian APKG 1; (4) Melakukan analisis kemampuan guru dalam melaksanakan pembelajaran dengan alat penilaian APKG 2; (5) Melakukan diskusi refleksi dengan kolaborator melalui lembar diskusi refleksi; (6) Membandingkan hasil tindakan dengan indikator keberhasilan; (7) Menentukan langkah tindakan siklus II hasil diskusi refleksi berdasar kajian teori; (8) Menyusun instrumen rencana tindakan siklus II berdasarkan hasil refleksi dengan kolaborator.

\section{Hasil dan Pembahasan}

Pembelajaran bahasa Inggris selama ini, seringkali terjadi hanya guru yang aktif, sedangkan siswa hanya duduk mendengarkan ceramah. Pembelajaran seperti ini mengakibatkan kebanyakan siswa ada yang bermain sendiri, mengantuk dan suka ribut sendiri. Keaktifan dan minat belajar siswa pada mata pelajaran bahasa Inggris menjadi rendah sehingga rendah pula tingkat pemahaman dan keterampilan berbicara bahasa Inggris siswa.

\section{Hasil}

Kondisi proses pembelajaran ini berakibat keaktifan siswa dalam mengikuti pembelajaran masuk dalam kategori rendah. Hal ini ditunjukan hasil pengamatan dari 28 siswa hanya 5 siswa atau 17,86\% 
yang keaktifan dalam pembelajaran masuk kategori tinggi, 12 siswa atau 42,85\% keaktifan sedang, dan 11 siswa atau 39,29\% keaktifan rendah.

Siswa yang keaktifannya rendah 11 siswa atau 39,29\%, keaktifan sedang 12 siswa atau $42,85 \%$, keaktifan tinggi 5 siswa atau 17,86\%. Secara umum keaktifan dalam proses pembelajaran bahasa Inggris di SMP Negeri 2 Wanadadi Kelas VIIA adalah kategori rendah. Rendahnya keaktifan siswa berdampak juga pada rendahnya keterampilan berbicara Bahasa Inggris. Nilai tes prestasi belajar kondisi awal menunjukkan banyak siswa yang belum tuntas. Siswa yang mendapatkan nilai lebih besar atau sama dengan KKM yaitu 65 ada 12 siswa dengan ketuntasan belajar $42,85 \%$. Nilai tertinggi 80 , nilai terendah 50, dan rentang nilai 0-100 dengan nilai rata-rata 61,77 .

Dari hasil analisis tes diperoleh skor tertinggi, skor terendah, rerata dan ketuntasan belajar siswa. Setelah melaksanakan perbaikan pembelajaran siklus I, diperoleh data sebagai berikut. Data tentang keaktifan siswa diambil setelah melakukan pembelajaran pada akhir siklus I, instrumen data berupa lembar pengamatan yang terdiri dari 4 indikator. Dari data tersebut diperoleh keaktifan skor 1 kategori rendah, keaktifan siswa skor 2-3 kategori sedang, keaktifan siswa skor 4 kategori tinggi. Hasil selengkapnya disajikan dalam tabel distribusi frekuensi sebagai berikut.

Tabel 1 Daftar Distribusi Frekuensi Keaktifan Siswa pada Siklus I

\begin{tabular}{cccc}
\hline Rentang Data & Frekuensi & $\%$ & S x F \\
1 & 5 & $17,86 \%$ & 5 \\
$2-3$ & 8 & $28,57 \%$ & 23 \\
4 & 15 & $53,57 \%$ & 60 \\
Jumlah & 28 & $100 \%$ & 88 \\
\hline
\end{tabular}

Setelah pembelajaran berlangsung selama 3 kali pertemuan maka dilakukan tes praktik mata pelajaran bahasa Inggris. Dari hasil tes diperoleh data bahwa rerata 68,93; nilai tertinggi 83; nilai terendah 55; modus 75; dan ketuntasan belajar 71,43\%. 
Berdasarkan kriteria keberhasilan penelitian dapat disimpulkan bahwa (1) Keaktifan siswa kategori tinggi baru 15 siswa atau 53,57\% sehingga belum berhasil, karena kriteria keberhasilan penelitian ini $75 \%$ atau 17 siswa harus mempunyai keaktifan tinggi; (2)Prestasi belajar mata pelajaran bahasa Inggris nilai rata-rata baru mencapai 68,93 dengan ketuntasan belajar $71,43 \%$ sehingga belum berhasil. Berdasarkan kriteria keberhasilan nilai rata-rata diatas 65 tercapai tapi ketuntasan belajar belum mencapai $75 \%$.

Berdasarkan hasil diskusi dan refleksi bersama kolaborator, maka kekurangan yang harus diperbaiki dalam siklus 2 meliputi (a) merumuskan tujuan pembelajaran, (b) menyiapkan pertanyaan pembelajaran, (c) penataan ruang dan faslitas belajar, (d) melaksanakan penilaian proses, (e) mengaktifkan siswa, (f) melaksanakan bimbingan yang lebih merata, dan (g) melaksanakan diskusi dalam pembelajaran.

Akhirnya penulis dan kolaborator memutuskan untuk melajutkan siklus II dengan ketentuan (1) materi pembelajaran melanjutkan kompetensi dasar yang sama, (2) pembelajaran menerapkan model pembelajaran rolex berbantuan media boneter, (3) perbaikan pembelajaran dilaksanakan diskusi kelompok, dan (4) pembimbingan juga lebih merata pada setiap kelompok. Keaktifan siswa pada siklus II disajikan dalam tabel distribusi frekuensi berikut.

Tabel 2 Daftar Distribusi Frekuensi Keaktifan siswa pada Siklus II

\begin{tabular}{cccc}
\hline Rentang Data & Frekuensi & $\%$ & $\mathrm{~S} \times \mathrm{F}$ \\
1 & 1 & $3,57 \%$ & 1 \\
$2-3$ & 4 & $14,9 \%$ & 9 \\
4 & 23 & $82,14 \%$ & 92 \\
Jumlah & 28 & $100 \%$ & 102 \\
\hline
\end{tabular}

Setelah pembelajaran berlangsung selama 3 kali pertemuan maka dilakukan tes praktik keterampilan berbicara mata pelajaran Bahasa Inggris. Hasil tes diperoleh data rerata nilai 77,32, nilai tertinggi 90, nilai terendah 60, modus 83, dan ketuntasan belajar 89,29\%. Berdasarkan kriteria keberhasilan, 
maka diperoleh hasil bahwa (1) Keaktifan siswa sudah mencapai 23 siswa yang tinggi atau $82,14 \%$ sehingga sudah berhasil, karena kriteria keberhasilan 75\% atau 21 siswa; (2) Prestasi belajar dalam keterampilan berbicara teks descriptive nilai rata-rata mencapai 77,32 dengan ketuntasan belajar 89,29\% sehingga sudah berhasil karena kriteria keberhasilan nilai ratarata sama atau diatas 62 dengan ketuntasan belajar sama atau melebihi $75 \%$. Refleksi bersama kolaborator, memutuskan untuk menghentikan tindakan pada siklus II karena indikator keberhasilan telah tercapai.

\section{Pembahasan}

Sebelum dilakukan pembelajaran dengan menggunakan model pembelajaran rolex berbantuan media boneter, keaktifan siswa tinggi hanya 17,86\% atau 5 siswa dari 28 siswa. Dalam pembelajaran Bahasa Inggris, guru menggunakan metode konvensional atau ceramah, situasi kelas pasif.

Pada siklus I diperoleh hasil, siswa memiliki keaktifan siswa tinggi 15 siswa atau 53,57\%, siswa memiliki keaktifan sedang 8 siswa atau $28,57 \%$ dan siswa memiliki keaktifan siswa rendah 5 siswa atau $17,86 \%$. Ini berarti ada kenaikan keaktifan siswa tinggi dari kondisi awal 5 siswa menjadi 15 siswa. Hasil análisis keaktifan siswa agar menjadi jelas disajikan dalam bentuk diagram batang sebagai berikut.

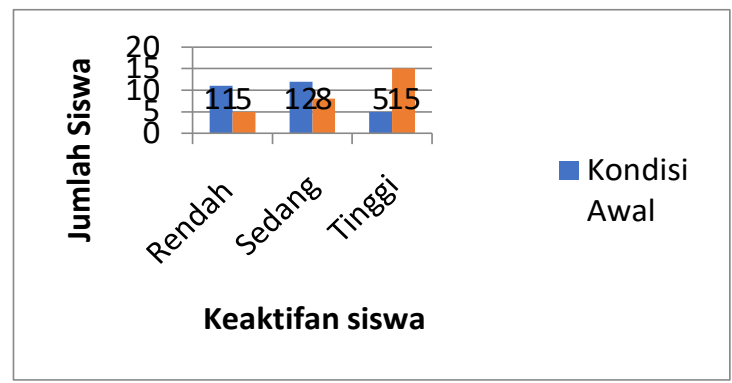

Grafik 1 Perbandingan Keaktifan siswa Kondisi Awal dan Siklus I

Nilai keterampilan berbicara pada siklus I hasil nilai tertinggi 83, nilai terendah 55, dan nilai rata-rata 68,93. Pada kondisi awal nilai ratarata 61,77 , sehingga ada kenaikan (rerata siklus I - rerata kondisi awal) 
51,08 dan ketuntasan belajar baru di siklus I mencapai 71,43\%. Hasil selengkapnya disajikan dalam grafik berikut.

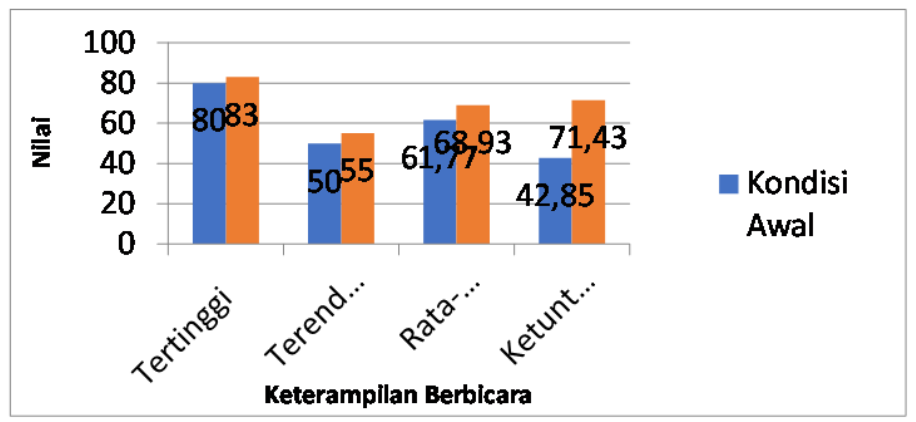

Grafik 2 Perbandingan Prestasi Keterampilan Berbicara Teks Descriptive Kondisi Awal dan Siklus I

Pada siklus II diperoleh hasil bahwa siswa yang memiliki keaktifan siswa tinggi 23 siswa atau 82,14\%; siswa yang memiliki keaktifan siswa sedang 4 siswa atau 14,29\%; dan siswa yang memiliki keaktifan siswa rendah 1 siswa atau 3,57\%. Ini berarti ada kenaikan keaktifan siswa tinggi dari siklus I ada 15 siswa menjadi 23 siswa pada siklus II. Hasil análisis keaktifan siswa agar menjadi jelas disajikan dalam bentuk diagram batang berikut.

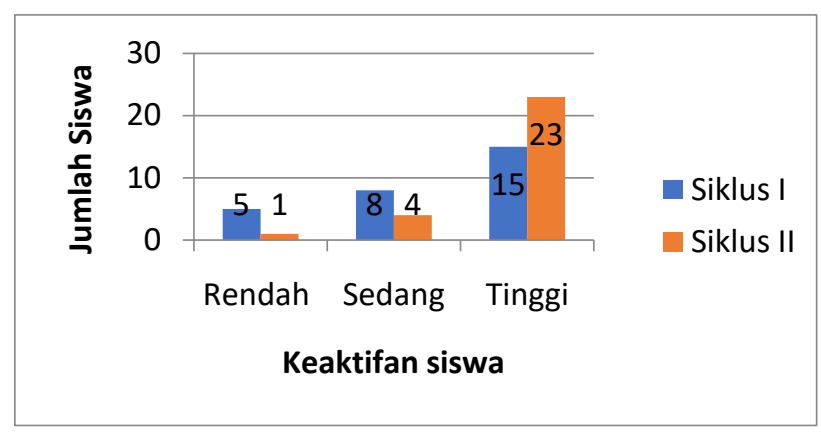

Grafik 3 Perbandingan Keaktifan Siswa pada Siklus I dan Siklus II

Pada siklus II hasil nilai keterampilan berbicara siswa tertinggi 90, nilai terendah 60 dan nilai rata-rata 77,32. Pada siklus I nilai rata-rata 68,93 sehingga ada kenaikan (rerata siklus II - siklus I) 8,39 dan ketuntasan belajar sudah mencapai $89,29 \%$. Hasil selengkapnya disajikan dalam grafik berikut. 


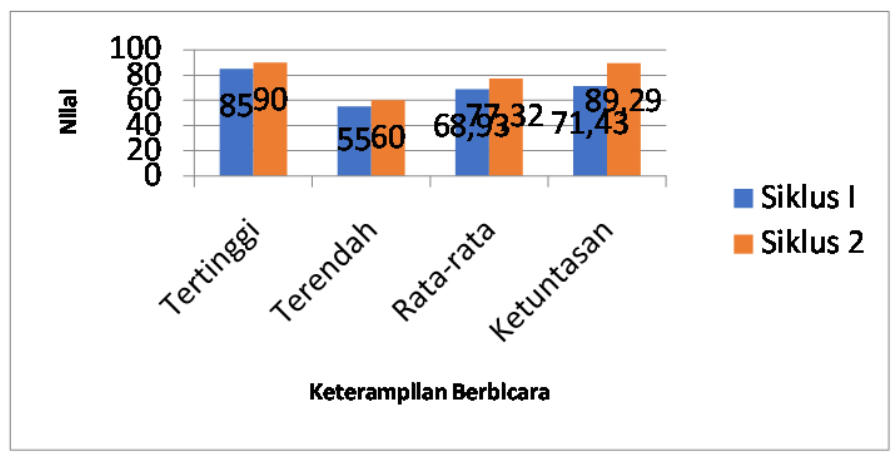

Grafik 4 Perbandingan Prestasi Keterampilan Berbicara Teks Descriptive Pada SiklusI dan Siklus II

Perbandingan hasil penelitian kondisi awal, siklus I, dan siklus II setelah dilakukan pengamatan pada saat proses pembelajaran diperoleh data sebagai berikut.

Tabel 3 Perbandingan Keaktifan Siswa Kondisi Awal, Siklus I, dan Siklus II

\begin{tabular}{clccc}
\hline No & Keaktifan siswa & Kondisi Awal & Siklus I & Siklus II \\
1 & Tinggi & 5 & 15 & 23 \\
2 & Sedang & 12 & 8 & 4 \\
3 & Rendah & 11 & 5 & 1 \\
\hline
\end{tabular}

Pembelajaran dengan model pembelajaran rolex berbantuan media boneter dapat meningkatkan keaktifan siswa yang tinggi dari 5 siswa pada kondisi awal menjadi 19 siswa pada siklus II. Semua siswa memperhatikan guru, aktif terlibat dalam pembelajaran dan mengaplikasikan apa yang diperoleh dalam proses belajar mengajar tersebut. Sebagian besar siswa juga berani mengeluarkan ide dan gagasannya serta tidak malu untuk bertanya.

Prestasi belajar mata pelajaran Bahasa Inggris yang diukur melalui tes praktik berbicara teks descriptive menunjukkan hasil pada kondisi awal rerata $61,77 \%$ dan ketuntasan 17,86\%. Setelah dilakukan pembelajaran dengan menggunakan model pembelajaran Rolex berbantuan media Boneter ada peningkatan. Pada siklus I rerata 68,93 dan ketuntasan 71,43\%. Dari hasil refleksi hasil tersebut masih belum mencapai indikator keberhasilan. Dengan 
memperbaiki kekurangan yang ada pada siklus I yaitu memperkecil kelompok hasil tes prestasi keterampilan berbicara teks descriptive pada siklus II rerata 77,32 dan ketuntasan 89,29. Setelah penerapan model pembelajaran rolex berbantuan media kosa kata bahasa Inggris siswa semakin banyak. Ini terlihat siswa bisa berdialog dengan kalimat yang panjang dengan menggunakan pilihan kata yang tepat. Siswa juga bisa bertanya jawab dengan lancar, bisa bertanya dan menjawab pertanyaan temannya dengan jawaban yang benar dan berbobot. Hal ini menunjukkan bahwa siswa juga meningkat pesat dalam aspek pemahaman dan kelancaran. Tata bahasa yang digunakan siswa ada beberapa yang masih salah, begitu juga dalam pengucapannya tapisecara keseluruhan sudah cukup meningkat. Perbandingan hasil tes prestasi belajar kondisi awal, siklus I dan siklus II setelah dilakukan ulangan pada akhir siklus diperoleh data sebagai berikut.

Tabel 4 Perbandingan Prestasi Keterampilan Berbicara Bahasa Inggris Kondisi Awal, Siklus I, dan Siklus II

\begin{tabular}{llccc}
\hline No & \multicolumn{1}{c}{ Prestasi Belajar } & Kondisi & Siklus I & Siklus II \\
& Keterampilan Berbicara & Awal & & \\
1 & Nilai tertinggi & 80 & 85 & 90 \\
2 & Nilai terendah & 50 & 55 & 60 \\
3 & Nilai rata-rata & 61,77 & 68,93 & 7,32 \\
4 & Ketuntasan Belajar & 17,86 & 71,43 & 89,29 \\
\hline
\end{tabular}

Pada siklus II proses pembelajaran menjadi lebih baik karena penerapan model pembelajaran rolex berbantuan media boneter sudah dilaksanakan dengan baik oleh siswa. Pembelajaran lebih menyenangkan karena siswa mengalami praktik berbicara secara langsung. Media pembelajaran juga menarik dan merangsang minat untuk belajar karena bisa mengenal karakter orang dan menyikapi karakter orang yang berbeda-beda melalui boneka karakter yang digunakan. Hal ini menyebabkan keaktifan siswa dan prestasi belajar menjadi meningkat. Jadi Boneter adalah media yang tepat untuk pembelajaran siswa. Hal ini sesuai dengan pendapat 
Sadiman (2001) yang menyatakan bahwa pikiran, perhatian, perasaaan dan minat siswa harus dirangsang agar proses belajar terjadi dengan melalui media.

Menurut Djamarah (2002) diskusi merupakan teknik belajar mengajar yang dilakukan oleh guru di sekolah. Didalam diskusi ini proses belajar mengajar terjadi, dimana interaksi antara dua individu atau lebih yang terlibat, saling tukar menukar pengalaman, informasi, memecahkan masalah dapat terjadi menjadikan semua aktif. Teknik diskusi juga terjadi dalam model role exchange yang merupakan inovasi dari peneliti. Penerapan model pembelajaran rolex dengan media boneter materi teks descriptive pada siswa kelas VIIA SMP Negeri 2 Wanadadi, ini dapat meningkatkan keaktifan dan keterampilan siswa dalam berbicara Bahasa Inggris. Hal ini sesua dengan teori pembelajarn mengenai keaktifan dan keterampilan berbicara disamping suasana pembelajaran yang menyenangkan.

\section{Penutup}

\section{Simpulan}

Model rolex berbantuan media boneter pada pembelajaran bahasa Inggris membuat perubahan dengan meningkatkan kemampuan baik sikap positif sebagai proses dan keterampilan siswa sebagai hasil. Aspek yang dicapai siswa antara lain (a) meningkatkan keaktifan siswa dalam pembelajaran dan (b) meningkatkan keterampilan berbicara bahasa Inggris siswa.

\section{Saran}

Guru disarankan lebih kreatif untuk meningkatkan proses pembelajaran dengan menggunakan media, model atau metode yang menarik supaya siswa lebih aktif dan terlibat dalam proses pembelajaran. Model pembelajaran rolex berbantuan media boneter salah satu yang disarankan teutama dalam meningkatkan keaktifan dan keterampilan berbicara Bahasa Inggris siswa. Model ini dapat dikembangkan dengan tema dan topik lain yang menarik dan bervariasi agar keaktifan siswa dan keterampilan berbicara siswa meningkat dan berkembang. 


\section{Ucapan Terima Kasih}

Penulis menyadari bahwa artikel ini tidak dapat terselesaikan tanpa bantuan dari berbagai pihak. Oleh karena itu penulis menyampaikan terima kasih kepada: Kepala Dinas Pendidikan Kepemudaan dan Olahraga Kabupaten Banjarnegara yang telah memberikan motivasi dan arahan untuk menyusun karya ilmiah tentang pembelajaran di lingkungan Dinas Pendidikan, Kepemudaan dan Olahraga, (b) Pengawas Sekolah yang telah memberikan bimbingan sehingga terselesaikannya artikel ilmiah ini, (c) Kepala Sekolah yang telah memberikan arahan dan bimbingan selama melakukan inovasi pembelajaran dan menyusun artikel ini; (d) Para guru SMP Negeri 2 Wanadadi yang telah membantu dan memberikan inspirasi dan semua pihak yang telah membantu menyelesaikan artikel ilmiah ini.

\section{Daftar Referensi}

Brown, H. (2004). Language Assessment: Principles and Classroom Practices. New York: Title. Perason Education Company.

Budi Pratiwi, E. (2013). Improving The Writing Skill of The Tenth Grade Students at SMA Berbudi Yogyakarta by Using Videos in the Academic Year of 2011/2012. No Title. UNY, Ac.Id.

Djamarah, S. B. (2002). Strategi Belajar Mengajar. Bandung: Rineka Cipta.

Harmer, J. (2001). How to Teach English. Pearson Education Limited.

Mentri Pendidikan dan kebudayaan. (2016). Standar Proses Untuk Satuan pendidikan Dasar dan Menengah.

Rahmah, M. (2019). Penggunaan FLAVID pada Procedure Text untuk Meningkatkan Kemampuan Berbicara Bahasa Inggris. Didaktika Pendidikan Dasar, 3(1), 201-216.

Sadiman, A. S. eta. (2001). Media Pendidikan: Pengertian, Pengembangan, dan Pemanfaatannya. Bandung: Rajawali Press.

Siswanti, A. (n.d.). Upaya Meningkatkan Kemampuan Berbicara Dengan Menggunakan Media Boneka Tangan pada Anak Kelompok di TK Pembina Cawas Kabupaten Klaten Tahun Pelajaran 2011/2012. UNY, Ac.Id, http://jurnal.fkip.uns.ac.id/index.php/paud/article/view/931 
Sudjana, N. (2001). Penilaian Proses Hasil Belajar Mengajar. Bandung: Remaja Rosdakarya.

Trianto. (n.d.). Mendesain Model Pembelajaran Inovatif-Progesif Edisi 4. Jakarta: Kenca Pranada Media Group. 